\title{
O nascimento da música instrumental brasileira
}

O pianista Amilton Godoy ${ }^{1}$ conta neste depoimento sua trajetória de músico erudito apaixonado por música popular brasileira, tendo, no início de 1964, ajudado a fundar em São Paulo o grupo de musica instrumental Zimbo Trio, junto com Luiz Chaves (baixo) e Rubens Barsotti (bateria). Zimbo é uma antiga moeda do Congo e sua tradução para o português seria "boa sorte, felicidade e sucesso". Para o grupo que foi criado no momento de maior efervescência da música brasileira e participou do marco de referência desse período - o show O Fino da Bossa, realizado em 1964 no teatro Paramount -, os bons augúrios da moeda se realizaram. A partir do show, aquele espaço foi assumido como o novo templo da Bossa em São Paulo, mudando a escala desses eventos $e$ alterando as relações entre artistas $e$ promotores com o advento dos shows ao vivo, num salto para o grande mercado fonográfico. A carreira bem-sucedida do grupo conta com importantes premiações², e de lá para cá o Zimbo trilhou 43 anos de carreira e quase 50 discos gravados. Em 1973, os integrantes fundaram o Clam - Centro Livre de Aprendizagem Musical, com metodologia própria e responsável pela formação de mais de duas gerações de músicos de alto nível. Em 2001, com o agravamento da saúde de Luiz Chaves (já falecido), o grupo passou a contar com Itamar Collaço.

Por Consuelo Ivo ${ }^{3}$

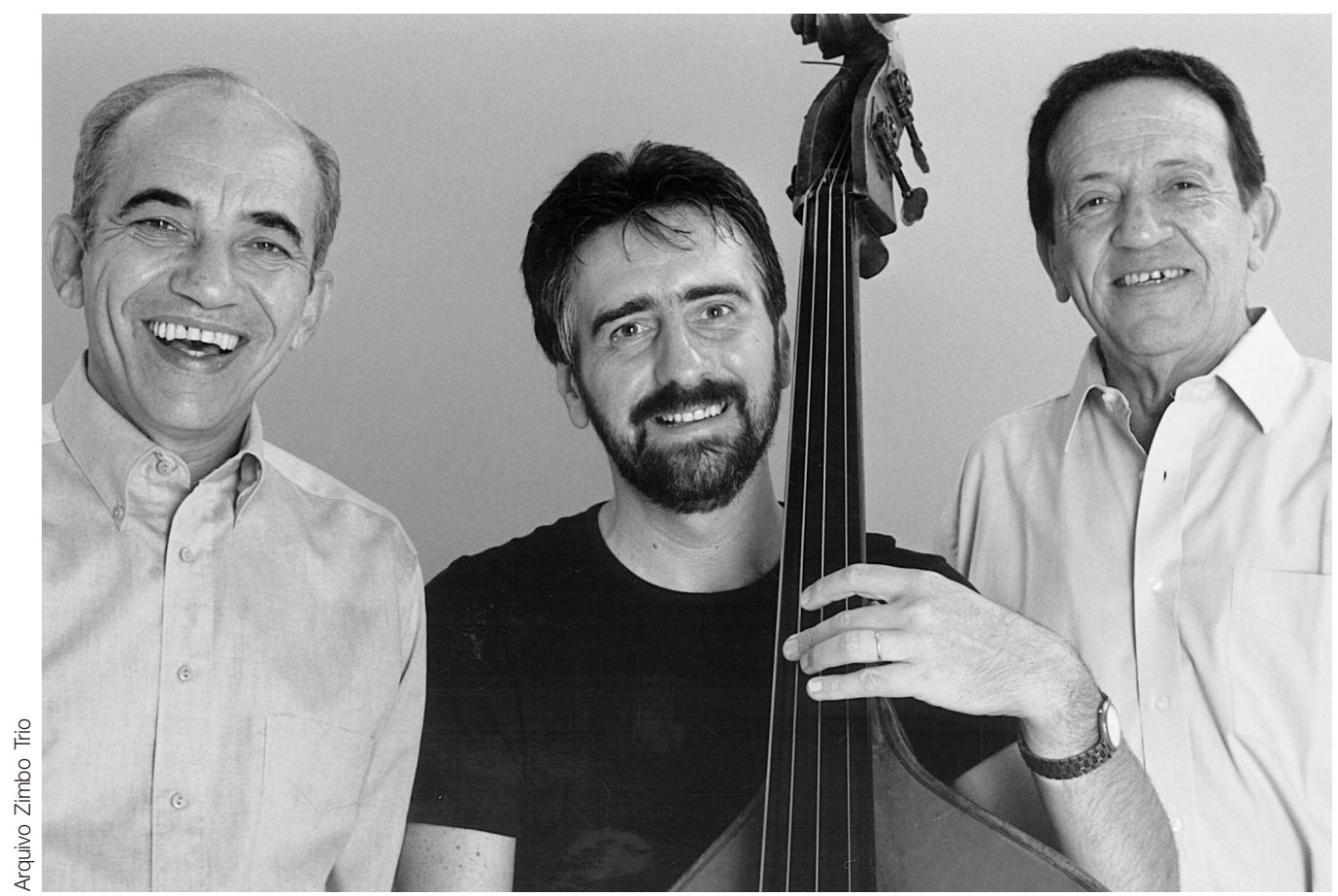

Da esquerda para a direita: Amilton Godoy, Itamar Collaço e Rubens Barsotti: o Zimbo Trio foi o primeiro grupo instrumental a utilizar temas brasileiros para fazer jazz.
1. Durante oito anos, foi membro da Comissão de Música da Secretaria de Estado da Cultura e do Conselho Estadual de Cultura de São Paulo. 
2. Ao longo de sua trajetória, conquistou no Festival de Mar del Plata (Argentina) o prêmio Cancioneiro das Américas e foi premiado pela participação na trilha sonora do filme Noite Vazia, de Walter Hugo Khouri. Por diversas vezes, foi premiado como Melhor Conjunto Instrumental, tendo sido agraciado com o Troféu Imprensa, Troféu Chico Viola, Medalha de Ouro dos Diários Associados, Prêmio Roquette Pinto, Prêmio Euterpe, Pinheiro de Ouro, Índio de Prata Candido Mendes e VII Prêmio Sharp de Música, entre outros. No exterior recebeu uma indicação ao Grammy (EUA)

3. Jornalista especialista em Gestão da Comunicação pela ECA-USP, é editora executiva da revista Comunicação \& Educação.

4. ZIMBO Trio. Rio de Janeiro: RGE, 1964. v. 1, 1 LP.
Minha família toda é de Bauru (SP) e fui criado numa atmosfera musical. Meu pai e seus irmãos eram músicos, minha mãe tocava piano e depois ela foi regente de coral. Isso é de fundamental importância, porque você começa a se musicalizar naturalmente. Meu pai exercia três atividades profissionais, e uma delas como músico profissional; tocava toda noite numa boate de Bauru e participava da pequena orquestra sinfônica da cidade, organizada pelo professor Brito. Ela tinha bons músicos; conheci alguns deles e assisti a muitos ensaios. Meu irmão mais velho, Adilson, e o caçula, Amílson, também se interessaram pela música e já éramos fanáticos quando crianças. Nossa educação foi muito diferenciada, naturalmente, por esse convívio familiar com a música e o incentivo para a educação musical.

Vivíamos numa época em que não existia a televisão. Cheguei a conhecer um aparelho tocado a manivela, com discos de 78 rotações. Tinha de cuidar para não cair a rotação e, mesmo assim, o som ficava muito comprometido. Depois é que vieram os primeiros sistemas de som com mais fidelidade, e bem depois os de alta fidelidade. Então não se falava em som estéreo, isso não existia, nem quando fizemos o primeiro disco do Zimbo ${ }^{4}$, vinte e poucos anos depois desse primeiro contato com o gramofone do vizinho. $\mathrm{O}$ rádio estava dando os primeiros passos. Ouvia a Rádio Nacional, e a primeira vez que escutei o Oscar Peterson tocar jazz no piano foi na Voz da América, um programa que ia ao ar depois da meia-noite, com aquele chiado todo. Me perguntava: "Como é que esse cara toca isso?", porque estávamos mais acostumados com a música erudita. Mais tarde um pouco, ouvíamos também orquestras americanas; meu pai gostava muito de Tommy Dorsey, com aquele som maravilhoso que ele tirava do trombone. Ouvíamos também o Artie Shaw, Glenn Miller, que era um sucesso, Stan Kenton e, um pouco mais à frente, a orquestra de Count Basie, com uma banda bem avançada de jazz. Os discos chegavam com muito atraso no interior do Brasil. Nasci em 1941, e a Guerra terminou em 1945; então, fui ouvir essas bandas e orquestras por volta de 1947, 1948.

Lembro-me, garoto ainda, das reuniões de família em que meu pai tocava violino e o irmão dele, Josino, violão; um outro irmão era trompetista, tio João Godoy, que se transformou num magnífico professor e ficou famoso no Brasil como o primeiro trompetista de um naipe (spalla), e um outro, tio Plínio Godoy, era cantor. E pelo lado da minha mãe, meu avô também tinha alguma formação; ele tocava um instrumento árabe, o alaúde, minha mãe tocava piano e o irmão dela, tio Célio, que foi diretor artístico da TV Rio, era maestro, também nascido em Bauru.

Nós, com 12, 13 anos, tínhamos uma opinião formada sobre o que entendíamos como boa ou má qualidade de música. Em Bauru, a nossa professora, Nida Marchione, viva até hoje, dizia ao nosso pai: "Esses meninos têm que ir embora daqui, pois a cidade já não oferece mais condições para o desenvolvimento musical que eles alcançaram”. Ela era fanática pela formação em piano oferecida em São Paulo pela escola da Magda Tagliaferro. 
Nessa época eu já tocava música popular, inclusive acompanhando o meu pai, e a professora de Bauru implicava muito com isso, chegando a deixar de nos dar aula por não concordar. Até hoje ela lamenta isso. Um outro professor, Efísio Aneda, também de Bauru, acabou nos aceitando e ainda ficamos dois anos com ele. Meu pai gostava muito de tocar tango em casa. Meu irmão Adílson tocava muito bem o acordeão e eu, o piano. Fazíamos baile pelo interior e também atuávamos na orquestra. Nessa época, eu estava com uns quinze anos. Meu pai tocava violino e um amigo dele, Montanha, tocava de vez em quando um clarinete; assim, reproduzíamos por inteiro tangos de Miguel Caló, famosos na Argentina.

Aquilo foi uma escola para mim. E tinha que tocar direito, porque meu pai dava uma arcada na minha cabeça quando eu tentava inventar alguma coisa. Eu já estava gostando de jazz e queria improvisar, mas não podia... ali não. Tudo isso foi parte de uma formação e me ajudou muito, e ao meu irmão também.

\section{MÚSICA, ESCOLA DOS SENTIDOS}

Relato essa atmosfera familiar para mostrar a importância de tudo isso numa época em que não existia o rádio nem a televisão como conhecemos hoje. Acompanhávamos o que acontecia em relação à reprodução de música no mundo através do interesse dessas pessoas todas da minha família, sempre voltadas para alcançar a qualidade, sempre por exigência deles, de meus pais, tios.

Hoje isso pode ser feito na escola de música, quando não é possível essa convivência para a criança dentro de casa. A escola de música do Zimbo Trio, o Clam ${ }^{5}$, nasceu também para oferecer essa possibilidade. Digo sempre aos pais: "Não deixem de oferecer isso... é preciso sensibilizar o ser humano desde muito cedo".

É possível desenvolver a capacidade auditiva para distinguir sons, instrumentos e formações diferentes de forma muito rica e prazerosa. Como tive esse privilégio, fui capaz de me apaixonar primeiro pela música de maneira geral. O amor ao piano talvez se explique por ser um instrumento polifônico, isto é, reproduz mais de um som ao mesmo tempo e, por isso, pode fazer harmonia, pode fazer melodia ou, ainda, induzir ritmicamente; então, é quase por si só um instrumento completo. Na cabeça dos meus pais isso era o que importava, ou seja, temos que colocar nossos filhos para estudar piano, não música, o que é bem diferente hoje.

O piano é um dos instrumentos possíveis. Se você se identificar com ele, pode vir a se tornar um grande músico, mas poderá ser também virtuoso tocando sax, flauta ou qualquer outro instrumento. Mas, para uma criança, o importante é que, ao ouvir esses sons, ela passa a perceber uma diferença dos timbres, e sua formação torna-se natural por conta da exigência, da excelência que tais percepções provocam nela. Assim, deixa-se de aceitar qualquer coisa.

5. <http://www.clamzimbo.com.br>. 


\section{NOS TRILHOS PARA SÃO PAULO, A DESCOBERTA DO TALENTO}

Para ir a São Paulo estudar havia apenas uma possibilidade, porque não tínhamos meios para nos manter na capital. E o jeito foi viajar toda quintafeira, de Bauru a São Paulo, naquela época em que o trem andava mesmo nos trilhos. Saía às 6 h10 de Bauru e chegava às 12h23 em São Paulo. Na Estação da Luz tomava um ônibus para a Sé, onde baldeava para a Vila Mariana. Recebia aulas das 14 às 16 horas com a dona Nellie Braga e às 17 horas tomava o trem de volta para minha cidade, chegando em casa por volta de onze e meia da noite. Fiz isso durante quase três anos!

Eu não tinha a menor idéia se isso iria dar certo ou não, mas era um gostar tão grande de música que, além das treze horas de viagem, por ser menor, eu precisava da autorização do meu pai para viajar sozinho. Mas eu ia e participava de tudo o que era possível. Depois de um ano e meio, as pessoas em São Paulo e dona Madalena, que sempre realizava aulas públicas, começaram a dizer que eu tinha jeito, talento para a coisa, e passaram a me incentivar.

Conheci nesse período toda uma geração de pianistas eruditos, a carreira que havia escolhido. Naquele momento era o grande caminho oferecido para quem desejava ser alguém. Nós não tínhamos uma geração de pianistas brasileiros tocando música popular ainda. E isso começou com o Zimbo Trio praticamente. Então, estudava muita música erudita. Me lembro quando saiu no jornal da minha cidade a notícia: "Bauruense toca no Teatro Municipal", pois era lá que as aulas públicas eram realizadas.

Tudo ia bem. Aconteceu o primeiro concurso de Piano Eldorado: João Carlos Martins foi premiado com o primeiro lugar e recebi uma menção honrosa. O concurso era muito difícil e com candidatos que tocavam muito bem. Por estar começando, nem imaginava chegar às finais. Eles souberam do meu esforço, da dificuldade da viagem a São Paulo e me deram uma bolsa de estudos que cobria exatamente uma pensão. Consegui me instalar numa bem próxima à escola, além de a proprietária ter um piano em casa que permanecia o dia todo fechado. Então, eu ficava perto da minha professora e ainda tinha o piano da dona da pensão para estudar o dia inteiro!

Passei a ter aulas duas vezes por semana e, daí sim, comecei a estudar muito. Minha mãe, obviamente, queria vir para São Paulo, não me queria longe de casa, mas meu pai ainda não estava aposentado. De todo modo, morar em São Paulo permitiu minhas idas aos teatros para assistir aos concertos de outros pianistas. Nos anos seguintes obtive boas classificações em importantes concursos nacionais de piano ${ }^{6}$. No ano de nascimento do Zimbo Trio, 1964, eu estava com 24 anos.

\section{O QUINTETO QUE VIROU TRIO}

Nesse $\mathrm{ano}^{7}$ ganhei muita coisa boa, principalmente o Zimbo Trio, porque o baixista Luiz Chaves e o baterista Rubens Barsotti queriam um pianista para 
formar um grupo de música brasileira. Conhecia-os por freqüentar a Baiúca, onde eles tocavam, e porque eu era fã de música popular. Precisei fazer uma opção, pois a proposta deles era séria; o Zimbo inicialmente era para ser um quinteto, já que outros dois músicos também haviam sido convidados e desistido, porque tinham muitos bailes para fazer. O Zimbo era uma idéia na cabeça do Rubinho. Ele estava com o Luiz Chaves na cidade de Portillo, no Chile, fazendo uma temporada, e desejou voltar para o Brasil e criar uma banda de músicos. Acho que estavam cansados de fazer "música de fundo de conversa". Eu tinha discos do Luiz Chaves e do Rubinho e nutria por eles grande admiração, pois eram dois exemplos de músicos bem-sucedidos. Durante cinco anos, foram os melhores do jazz em seus instrumentos, de uma seleção rigorosa feita por críticos da noite.

Esse namoro com eles começou no final de 1963. Me lembro de ter avaliado seriamente se ia ou não tocar com os dois, porque estava indo muito bem como músico erudito, estava fazendo gravações... Mas aquilo era uma paixão para mim, a coisa que mais queria era tocar jazz, fazer música boa e de nível. O jazz sempre foi referência para indicar um músico de qualidade, de maior conhecimento e desenvoltura. A música brasileira não tinha

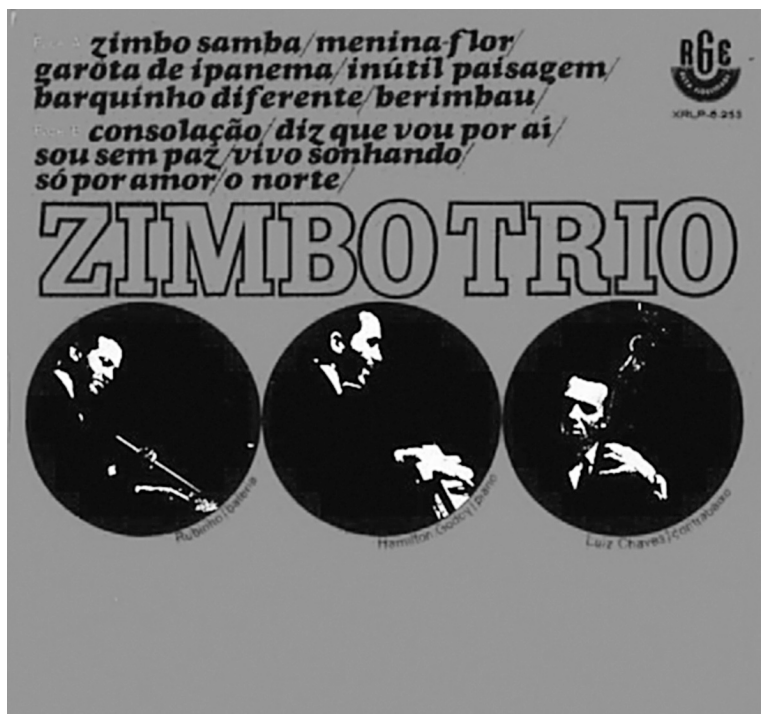

Capa do primeiro disco do Zimbo Trio, lançado em 1964 pela RGE. o seu jazz ainda e os músicos eram obrigados a se contentar com o suingue americano.

Os bons músicos sempre procuraram desenvolver novos e criativos caminhos para poder expor sua musicalidade. Desde antes da bossa nova, em 1958, alguns excelentes instrumentistas já se antecipavam na busca de uma linguagem jazzística brasileira. Tive a oportunidade de tocar durante dois anos no Quinteto de Jazz do Casé - apelido de José Ferreira Godinho Filho, considerado o melhor saxofonista daquela geração e grande precursor desse caminho musical, que acabou sendo denominado de samba jazz. O estilo pressupunha composições com suingue (balanço) brasileiro, muitas improvisações com temas sustentados por sofisticadas harmonias e com grande variedade rítmica totalmente inspirada em nossas raízes e em nosso folclore. Conseqüentemente, o músico precisava ter vasto conhecimento musical e total domínio do seu instrumento para poder participar dessa proposta.

Em casa sempre houve incentivo para os dois gêneros musicais, ou seja, para música erudita e música popular; nunca existiram barreiras, pois meu pai sempre gostou de música boa. As orquestras brasileiras que ouvíamos eram do 
comunicação \& educação • Ano XII • Número 3 • set/dez 2007

Severino Araújo, do Sílvio Mazzuca e uma outra do interior, do Nélson, de Tupã. Quando eles iam para Bauru, meu pai me levava e a gente adorava. Nunca houve intransigência, porque sempre vai existir música boa ou má, em qualquer gênero. Ouvíamos muito também o Orlando Silva, a Aracy de Almeida...

Foi muito difícil para meu pai aceitar o João Gilberto. Ele dizia: "Esse cara não é um cantor, ele só fala", isso porque era uma nova forma de se expressar. Eu fiquei doido com aquilo, pois achava que a música tinha que ser por ali... aquele violão, uma harmonia diferente... ${ }^{8}$

Isso foi em 1958/1959! Depois a bossa nova deu uma parada, ficou intimista. A música brasileira só retornou com toda força em 1964, quando os músicos passaram a ter grande sucesso em seu próprio país. O Zimbo Trio foi o primeiro grupo instrumental a utilizar temas brasileiros para fazer jazz. Esse, em minha opinião, foi o grande mérito do Zimbo. Com isso influenciou um número elevado de músicos no Brasil e no mundo.

\section{ENCONTROS E O GRANDE MOMENTO DA MÚSICA BRASILEIRA}

Curiosamente isso tudo ocorreu com o advento da televisão no país, e num momento em que a música alcançava os grandes festivais, com uma qualidade incomparável de talentos jovens. Hoje, olhando para esse período, é possível dizer que não nos dávamos conta do que aquilo representaria mais tarde para a música brasileira. Quando você está dentro do processo, não tem condições de perceber claramente. Você não vê a paisagem, é parte dela. Gostávamos muito do que fazíamos, mas, sinceramente, não tínhamos essa noção. Era uma vontade de realizar coisas boas, de romper com uma porção de coisas rançosas e antigas, com preconceitos de ordem musical, pois tudo era muito forte e estávamos enlevados.

O fato de você cruzar na vida com pessoas que o ajudam a realizar seu sonho é também muito importante. O momento foi bem oportuno, já que, no Brasil, os estudantes todos estavam querendo mudanças, e tivemos uma sorte danada de começá-las naquele momento. Em São Paulo, o público universitário era nosso forte, e nascíamos junto com aquela efervescência cultural.

Também nos procuravam muito para dar aulas, porque ninguém ensinava nas escolas de música aquilo que estávamos criando, gravando. Aliás, os músicos nesse período eram muito bem remunerados, disputados pelas casas noturnas que embalavam as noites com música ao vivo. A música americana perdia território, e esses espaços foram ocupados por músicos como nós. Éramos encontrados na

8. CHEGA de Saudade Odeon: Rio de Janeiro, 1959. 78 rpm. Faixas "Chega de Saudade", de Tom Jobim e Vinicius de Morais, de um lado, e "Bim bom", de João Gilberto, de outro. rua Major Sertório, a Brodway brasileira, assim conhecida por abrigar as boates mais requintadas, além de no Baiúca, que ficava na praça Roosevelt.

Quando formamos o Zimbo Trio, deixamos de tocar na noite e elegemos o palco. E desde seu começo o Zimbo foi uma surpresa atrás da outra. Alcançamos as paradas de sucesso no Brasil fazendo música instrumental, até então inconcebível. Numa revista americana de música você encontrava os Beatles 
em terceiro lugar e o Zimbo em primeiro na venda de discos no Brasil. Isso aconteceu - de a música popular brasileira ocupar um espaço nobre no cenário nacional.

Iniciamos com apenas uma faixa no disco intitulado O Fino da Bossa e depois gravamos o primeiro disco do Zimbo, com o qual ficamos seis meses nas paradas de sucesso do país, e com reflexos no mundo. As gravadoras lançaram nossos discos nos Estados Unidos, na Inglaterra, e a cotação deles subiu muito de nível. A Dawnbeat, revista especializa em jazz, nos deu uma cotação máxima para um volume que saiu pela Pacific Jazz.

Assim nos tornamos conhecidos, e os músicos que antes eram nossos ídolos, passaram a nos assediar como fãs. Isso é muito curioso, engraçado... A primeira viagem do Zimbo ao exterior foi ao Peru. Levamos a Elis Regina como crooner. No final de 1964, ganhamos o prêmio Roquete Pinto: nós como grupo, ela como cantora e o Wilson Simonal como cantor. No início de 1965, o prêmio foi entregue no teatro da Record e fizemos uma apresentação no final,

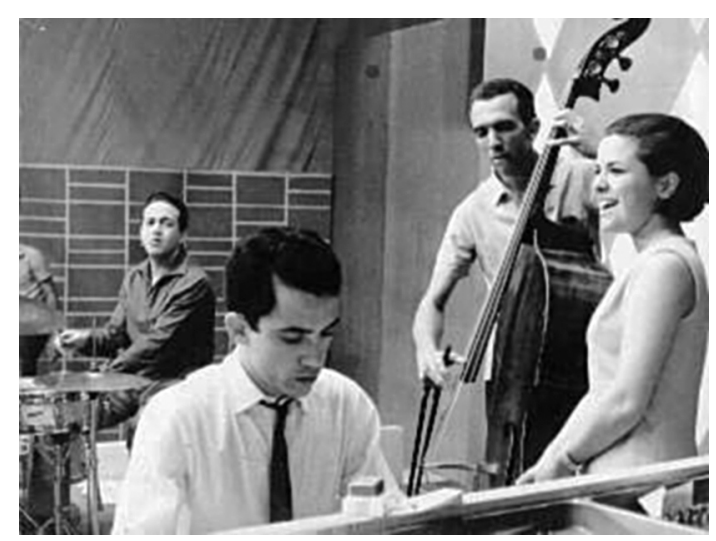

Zimbo e Elis no programa O Fino da Bossa. tocando uma música instrumental, com a participação de Elis e Simonal. O Paulo Machado de Carvalho achou que aquilo poderia ser a base para um programa musical e nos convidou para fazê-lo. Nascia o Fino da Bossa, sem o Simonal, pois ele tinha um contrato com a TV Tupi. O Jair Rodrigues havia recebido o prêmio Revelação e acabou formando dupla com a Elis. E o programa, durante quase três anos, ditou os rumos da música brasileira, transformando-se num importante catalisador de talentos.

Tudo que havia de mais importante na música brasileira convergia para lá, pois a qualidade determinava o que deveria acontecer.

\section{ACORDES SUBVERSIVOS}

Quando a ditadura militar entrou no seu pior e mais negro período, todos sentimos a perseguição; foi muito triste e difícil, porque ela era declarada. Muitos de nós sobreviveram com os shows internacionais, em função do interesse despertado até então. De resto, o que estava claro era que a memória tinha de ser apagada, e tudo foi muito bem orquestrado.

Quando você forma muito bem as pessoas e elas são capazes de adotar critérios próprios de avaliação, para discernir entre o que é bom ou ruim, para ser formada ou bem informada do que é nacional ou não, do que deve ou não ser prestigiado, ou do que contribui para a valorização do ser ou de sua sensibilização, é preciso tirar delas todas essas condições num regime de exceção. É necessário 
9. TERRA de Ninguém. De Marcos Valle e Paulo Sérgio Valle.

10. APESAR de você. Chico Buarque. (C)1970 by Cara Nova Editora Musical Ltda.

que um mande e todos os outros obedeçam. Então você tem um poder maior que sobrepuja todos os diretos constitucionais, individuais das pessoas.

Chegamos ao absurdo de ter de submeter à censura um disco instrumental! O Zimbo era muito ligado a músicos evoluídos e protestava onde fosse necessário - o MST é brincadeira perto das músicas de protesto que se fazia na época. Veja, como exemplo, o prefixo do programa O Fino da Bossa, com a música Terra de Ninguém:

Mas um dia vai chegar/Que o mundo vai saber/Não se vive sem se dar/Quem trabalha é quem tem/Direito de viver/Pois a terra é de ninguém ${ }^{9}$.

A gente contestava e lutava contra as injustiças sociais, e a música era usada de maneira inteligente, a ponto de se prejudicar no quesito qualidade, porque, o que importava, era o nível do protesto, o que precisávamos dizer através dela.

Em uma ocasião, estávamos no Rio de Janeiro para participar de um programa ao vivo, e a censura chegou com aquela pressão e coisa e tal... A gente tentando explicar que o Zimbo era um grupo instrumental etc. Até que eu disse uma frase ao censor que ficou na história, diante da insistência dele em nos acompanhar: "Então, você fica aí e veja se eu faço algum acorde subversivo...". Ainda assim, é notório que a maior perseguição foi sofrida pelos compositores, mas o Zimbo ficou também sem o que tocar, muitas vezes, porque uma música poderia estar atrelada a essa situação. Por exemplo, recolheram o disco do Chico Buarque com a música Apesar de Você:

Hoje você é quem manda/Falou, tá falado/Não tem discussão/A minha gente hoje anda/Falando de lado/E olhando pro chão, viu/Você que inventou esse estado/E inventou de inventar/Toda a escuridão/Você que inventou o pecado/Esqueceu-se de inventar O perdão/Apesar de você/Amanhã há de ser/Outro dia/Eu pergunto a você/Onde vai se esconder/Da enorme euforia/Como vai proibir/Quando o galo insistir/Em cantar/ Água nova brotando/E a gente se amando/Sem parar ${ }^{10}$.

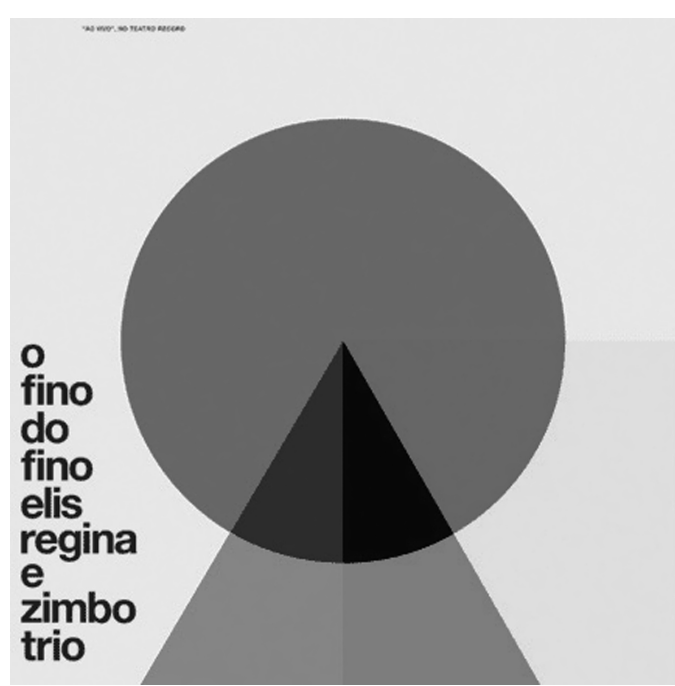

Capa do disco O Fino do Fino, de Elis Regina e Zimbo Trio, produzido por Carlos Prósperi, em 1965.
Mas nós já tínhamos gravado a música no nosso disco instrumental; então, até eles perceberem que a música era a mesma, o disco tocou que foi uma beleza no país inteiro. $\mathrm{Eu}$ ouvia aquele piano tocando em tudo que era rádio... Quer dizer, tudo era muito absurdo. $\mathrm{O}$ processo de desenvolvimento, de formação de pessoas, e a desenvoltura alcançada antes desse período da ditadura no país sofreram um impacto que até hoje estamos vivendo; e sabe-se lá quanto tempo mais vai ser preciso para recuperar o que se perdeu. E 
sentimos na pele os descalabros, as irresponsabilidades de pessoas que acabaram assumindo situações de comando sem ter o devido preparo. Por isso, nós somos as vítimas.

\section{UMA ESCOLA DE MÚSICA BRASILEIRA}

Antes da existência da escola de música fundada pelo Zimbo Trio, quem desejasse conhecer melhor o universo da música ficava restrito à formação dos conservatórios musicais. Se alguém quisesse ser um arranjador, ou adquirir conhecimentos em profundidade, principalmente em termos de conteúdo para fazer uma boa música instrumental, de jazz ou brasileira, não importa, não tinha a quem recorrer. No conservatório, você aprendia a tocar piano da forma ensinada pelo professor. A música passava a ser muito mais uma preocupação do que uma satisfação.

Decidimos colocar no papel nosso aprendizado para que, quem tivesse interesse, pudesse estudar com orientação, e não viver as dificuldades que passamos para alcançar esse mesmo conhecimento.

O Clam ${ }^{11}$ criou uma metodologia própria, inexistente até então. Fomos aconselhados à época a não ser uma escola regular, mas livre - por isso o nome Centro Livre -, pois de outro modo teríamos de dar satisfação às pessoas que não podiam compreender mais do que nós mesmos. E não era uma questão de saber mais ou menos, mas o quê sabíamos. Quem estava nas universidades ou nas escolas não tinha condições, mas nós podíamos fazer isso pelo país.

Nossa intenção também era tirar o atraso que existia sobre o conhecimento mais evoluído com relação à música. Não tive um pianista brasileiro em que me espelhar ou me inspirar, e penei muito para aprender sozinho o que faziam aqueles jazzistas que eu admirava. Quando passei a ser a inspiração para outros músicos, que me solicitavam e diziam querer aprender o que eu fazia, foi o momento de desenvolver uma metodologia. Criei um processo completo, fiz os modos de harmonia 1, 2, 3, 4, além da publicação de dois volumes bilíngües, que incluem dois álbuns de partituras e $\mathrm{CDs}^{12}$, e desejei poder assim formar toda uma geração de pianistas para passar isso adiante.

Desde a primeira turma tivemos muita sorte, porque vieram alunos muito bons, de talento, estudar no Clam. Na minha área de piano, por exemplo, contamos com Eliane Elias, Felix Wagner, hoje diretor de orquestra na Alemanha, o saudoso Nico Assumpção, contrabaixista, Ulisses Rocha, Grupo Dalma e tantos outros. Antes de ir para o palco e tornarem-se famosos, estudaram e depois trabalharam aqui como professores, sempre nesse percurso de transmitir conhecimento. Podemos afirmar, sem receio, que o Clam passou a ser um oásis na música. Foi um grande sucesso por não haver nenhuma escola com essa proposta.

A música popular tem outros valores, assim como o jazz. É a criatividade que conta. Você deve oferecer a ferramenta para a pessoa e ensinar o que se deve fazer com ela. Para isso é preciso conhecer música profundamente, co-
11. As atividades do Clam foram complementadas pela Clam Discos e Gravações (extinta) e, em 1979, pela Zimbo Edições Musicais, destinada à produção de material didático para os cursos da escola.

12. AURIEMO, Dulce; GODOY, Amilton. Piano solo: compositores brasileiros. São Paulo: Zimbo Edições Musicais, 1991. v. I.; GODOY, Amilton. Piano solo: compositores brasileiros. São Paulo: Zimbo Edições Musicais, 2000. v. II. 
nhecer harmonia. Recebemos alunos de todos os Estados e também fazemos intercâmbio com escolas internacionais, com alunos nossos surpreendendo pelo nível de conhecimento. Outro trabalho que merece ser mencionado é o dueto que fiz com Débora de Aquino e a gravação de um álbum com arranjos e transcrições para flauta e piano a partir do segundo volume da série Piano Solo: Compositores Brasileiros $^{13}$. A motivação veio de um pedido do primeiro flautista da Orquestra Filarmônica de Berlim, Michael Hasel, que havia sido presenteado com o CD da série pelo maestro Júlio Medaglia. É um trabalho que se encaixa na modalidade de apresentar música instrumental brasileira sem a preocupação com rótulos ou nomenclaturas. Apesar de ele ser perfeccionista, não exige a atenção da música erudita, mas exibe características extremamente populares no que diz respeito ao estilo musical brasileiro.

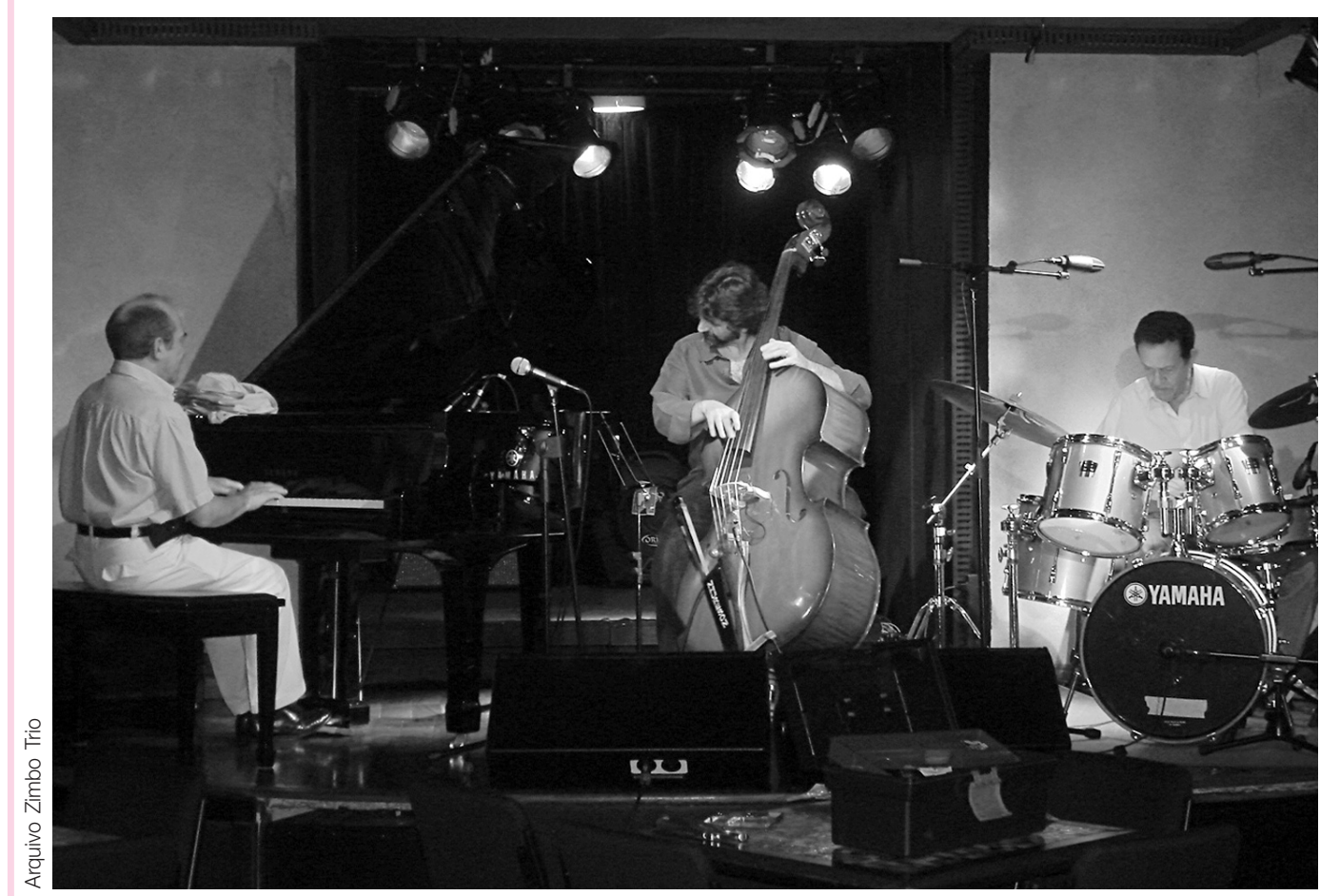

Zimbo: trabalhos realizados com orquestras sinfônicas do Brasil, Venezuela, Argentina, Uruguai e Colômbia, além de espetáculos no Phillarmonie de Berlin, Town Hall e outros.

Por outro lado, muitos de nossos músicos instrumentistas vão para exterior porque o mercado aqui é muito restrito. Ele é bom para o cantor. Quanto menos evoluída for a música tocada no Brasil, maiores suas chances com o público. Os grandes sucessos vêm da música primitiva; o primitivismo a que me refiro é o conhecimento exigido para se fazer uma música desse gênero. $O$ sujeito olha aquilo na $\mathrm{TV}$, vê aquele baita sucesso e acha que também pode ser um artista, aprendendo dois ou três acordes. E a televisão, esse grande veículo, acaba reproduzindo uma propagação que é cópia uma da outra, sem nenhum limite desse estado de percepção empobrecida. Não parece haver um compromisso de contribuir para melhorar o nível da platéia ou audiência. 
Nossa última experiência foi um programa na TV Cultura, o Café Concerto. Surpreendentemente foi obtendo audiência e sobreviveu durante dois anos. Muita gente boa que está por aí apareceu pela primeira vez em nosso programa. A proposta era oferecer uma chance para quem tivesse talento. Como somos dessa área, técnicos no assunto, percebemos antes do público, e até mesmo do grupo, quem tem conteúdo diferenciado. É muito importante estimular essas pessoas para que não se desviem nem acabem indo fazer outra coisa na vida, mudando o foco. Daí fica a impressão de que o Brasil não tem mais gente de talento, de que não está mais nascendo ninguém com talento. Como? Depois dessa turma do final da década de 1960 não surgiu mais ninguém?

Dizem que existe por aí uma música brasileira, mas não é porque ela é feita no Brasil que é brasileira. Se a formação da pessoa tem uma base alienígena, como o rock, por exemplo, não se pode dizer que tem raiz local, com conteúdo brasileiro. A música brasileira popular é tida no mundo como uma das melhores, mas no Brasil ainda misturam muito tudo isso; nem sempre o que se realiza em música aqui tem qualidade.

O fato é que suspenderam o programa e nunca recebemos nenhuma satisfação. Soubemos de uma fonte segura que o Café Concerto deixou de ir ao ar porque começou a dar audiência e, ao mudar de horário, passou a incomodar outras pessoas. Então, se uma televisão que tem a incumbência de manter o nível é assediada porque está tirando um ou dois pontos da TV comercial, onde iremos encontrar saídas possíveis?

Talvez, agora, as alternativas sejam as concessões de rádio ou canais na TV digital, mas para uma ou outra é preciso mudar esse estado de coisas no país. Por outro lado, podemos perguntar ao público o que ele tem achado da presença de um artista no Ministério da Cultura. Para o público mudou alguma coisa? Para mim não mudou nada. Eu tenho um excelente relacionamento com o Gil; o Zimbo gravou músicas dele, não misturamos as coisas. Ele tem ainda quatro anos para mostrar a que veio, mas para a música ele fez alguma coisa? Não sei.

De nossa parte restam algumas experiências ${ }^{14}$ interessantes e com a participação de escolas, como a que tivemos com a prefeitura de Diadema. Um ex-aluno, o José de Filipi, quando prefeito, fez um convênio com o Clam. Foi uma maravilha! Chegamos a tocar lá com orquestras formadas por nós. Enfim, quando tudo estava bem encaminhado, terminou o mandato do prefeito e o trabalho não continuou com seu sucessor.

O Clam tem capacidade para levar esse programa para qualquer escola. Tivemos experiências em Bauru, Araçatuba, sempre sob nossa supervisão e, ao final do ano, com a apresentação do Zimbo e os alunos. Fizemos um disco chamado Zimbo e as Crianças, realizado com crianças de 7 a 12 anos, com um repertório de alto nível. Num trabalho também para crianças, o projeto Espantaxim e o Castelinho Mágico ${ }^{15}$, criado por Dulce Auriemo, fui o arranjador das músicas. A intenção dela é contribuir para a Literatura Musical Infantil
14. Destacam-se os trabalhos realizados com orquestras sinfônicas do Brasil, da Venezuela, da Argentina, do Uruguai e da Colômbia, além de espetáculos no Phillarmonie de Berlin, Town Hall e outros.

15. <http://www.espantaxim.com.br>. 


\section{comunicação \& educação • Ano XII • Número 3 • set/dez 2007}

Brasileira. Reúne 14 canções inéditas apresentadas em um Livro-CD, contendo informações sobre o repertório, os aspectos pedagógicos, e letras acompanhadas de ilustrações e partituras.

Resumo: O pianista Amilton Godoy conta neste depoimento sua trajetória de músico erudito apaixonado por música popular brasileira. No início de 1964, ele ajudou a fundar em São Paulo o primeiro grupo de música instrumental brasileira - o Zimbo Trio. Integrante do momento de maior efervescência da música brasileira - sendo marco de referência desse período o show O Fino da Bossa, realizado em 1964 o músico relata como o cenário musical iniciado com a bossa nova e o samba-jazz contribui para a bem-sucedida trajetória do Zimbo Trio em 43 anos de carreira e quase 50 discos gravados. Em 1973, os integrantes do Zimbo fundaram o Clam - Centro Livre de Aprendizagem Musical, com metodologia própria e responsável pela formação de mais de duas gerações de músicos de alto nível.

Palavras-chave: música, música instrumental, bossa nova, samba-jazz, Zimbo Trio.
Abstracts: In this testimony, the pianist Amilton Godoy talks of his career as an erudite musician in love with Brazilian Popular Music. In 1964, in Sao Paulo, he took part in the foundation of the first group of Brazilian instrumental music - the Zimbo Trio. As participant of the Brazilian music major effervescence moment and of that period's milestone, the show O Fino da Bossa, taken in 1964, the musician tells how the musical scenery initiated with bossa nova and the samba-jazz contributed to the well-succeeded trajectory of the Zimbo Trio in 43 years of career and almost 50 albums. In 1973, the group members founded the Clam - Centro de Livre Aprendizagem Musical (Free Musical Learning Center) - that has a school with its own methodology and is responsible for the formation of more than two generations of high level musicians.

Keywords: music, instrumental music, bossa nova, samba-jazz, Zimbo Trio. 